\title{
3: 384700814-38499868
}

National Cancer Institute

\section{Source}

National Cancer Institute. 3: 384700814-38499868. NCI Thesaurus. Code C41646.

Physical location of ACVR2B_Gene 